\title{
РЕГЛАМЕНТАЦІЯ ПОВСЯКДЕННОГО ЖИТТЯ СІЛЬСЬКОГО НАСЕЛЕННЯ «ТРАНСНІСТРЇ̈» 1941-1944 РР.
}

Анотація: Проаналізовано закони та розпорядження румунської окупаційної адміністрації, які були направлені на регламентащію повсякденного життя сільського населення межиріччя Дністра та Південного Бугу в 1941-1944 рр. Встановлено, що переважна частина наказів була направлена на забезпечення безпеки окупаційних військ та адміністрації. Також зазначено, що низка наказів вводила норми покарання у вигляді штрафів та ув'язнень за спроби саботажу або відмови виконувати дані постанови. Також румунська адміністрація взяла під свій контроль норми споживання населенням продуктів харчування.

Зазначено, що на окупованих землях румуни зустрілися з неконтрольованим перебігом різноманітних захворювань, які намагалися ліквідувати впровадженням обов'якових правил підтримки особистої гігієни населення.

Ключові слова: окупащія, «Трансністрія», сільське населення, закони, харчування, хвороби

Історіографічною прогалиною дослідження, яке стосується окупаційної політики нацистської Німеччини та їі сателітів на захоплених ними територіях, є вивчення політики регламентації румунською адміністрацією повсякденного життя сільського населення «Трансністріі».

Стосовно історіографії порушеного питання слід зазначити, що радянська історіографія цього питання представлена дослідженнями М.Лєбєдєва ${ }^{1}$, I. Левіта ${ }^{2}$, С. Гратинича ${ }^{3}$ у у зарубіжній історіографії цієї проблеми торкнулися американський дослідник О. Даллін ${ }^{4}$, молдавська дослідниця Р. Соловей ${ }^{5}$, румунські дослідники І. Ністор ${ }^{6}$, К. Кіріцеску ${ }^{7}$ та російський історик О. Будницький ${ }^{8}$. Що стосується української історіографії

\footnotetext{
"Осипенко Олександр Валентинович - кандидат історичних наук, старший викладач кафедри українознавства, історико-правових та мовних дисциплін Одеського національного морського університету (Одеса, Україна);

ORCID: https://orcid.org/0000-0002-1213-0481; e-mail: osupenkooleksandr@ukr.net

${ }^{1}$ Лебедев Н.И. Крах фашизма в Румынии. Москва: Наука, 1976. 632 с.

2 Левит И.Э. Крах политики агрессии диктатуры Антонеску. Кишинев : Штиинца, 1983. 376 с.

${ }^{3}$ Гратинич С.А. На левом берегу Днестра 1941-1944. Странищы совместной борьбы трудящихся смежных районов Молдавии и Украины против немецко-румынских фашистских захватчиков. Кишинев: Картя Молдовеняскэ, 1985. 186 с.

${ }^{4}$ Dallin A. Odessa, 1941-1944: A Case Study of Soviet Territory Under Foreign Rule. RAND, RM-1875: California, 1957. 466 p.

${ }^{5}$ Solovei $R$. Activitatea Guvernamintului Transnistriei on domeniul social-economic si cultural: (19 auq. 1941 29 ian. 1944). Iasi, 2004. $182 \mathrm{p}$.

${ }^{6}$ Nistor I. Istoria românilor din Transnistria: organizarea, cultura şi jertfa lor. Bucureşti, 1995. 164 p.

${ }^{7}$ Kiriţescu C. România în al doilea război mondial: in 2 vol. Vol. 1. București : Universsul Enciclopedic, 1995. 360 p.

${ }^{8}$ Одесса: жизнь в оккупации. 1941-1944. История коллаборационизма / сост., отв. ред. и автор вступ. статьи О.В. Будницкий. Москва: Политическая энциклопедия, 2013. 231 с.
} 
даного питання, то слід виокремити групу науковців: Т.Нагайко ${ }^{9}$, Т. Пастушенко ${ }^{10}$, 0. Яшан ${ }^{11}$, які працюють у напрямку реконструкції повсякденного життя людини воєнного часу, переважно на тих територіях України, які були окуповані німецькими військами.

Висвітлюють повсякденне життя підокупаційного населення «Трансністрії» й південноукраїнські науковці. Н. Дейнека ${ }^{12}$ на сторінках свого дослідження розглянула репресивну політику окупантів, винищення єврейського населення та діяльність підпільників. Колектив одеських істориків, очолений М. Михайлуцою, подав загальну характеристику адміністративно-територіального поділу, соціально-економічного становища та культурного життя «Заддністрянщини» періоду 1941-1944 pp. ${ }^{13}$ Деякі аспекти повсякденного життя церковнослужителів у своїх монографіях розглянув М. Михайлуца ${ }^{14}$ В іншому досліджені науковець, дослідивши буденне життя православного кліру, констатує, що особливою полярністю відрізнялося життя місіонерів-прибульців і місцевих

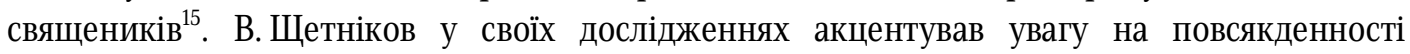
мешканців окупованої Одеси ${ }^{16}$, В. Остащук (Крикун) - запропонувала загальну картину функціонування медичних установ, закладів освіти в Одесі, упродовж 1941-1944 pp.". О. Бабіч опублікував низку архівних документів, наказів і розпоряджень румунської адміністрації, а також газетних вирізок статей, на основі яких спробував відтворити усі сфери життя буденного життя Одеси та її мешканців у роки окупації ${ }^{18}$.

Метою дослідження є регламентація румунською адміністрацією повсякденного життя сільського населення межиріччя Дністра та Південного Бугу в 1941-1944 pp.

Окупувавши землі межиріччі Дністра та Південного Бугу, румунське керівництво

\footnotetext{
${ }^{9}$ Нагайко Т. Життя селян на окупованій території України в роки Другої світової війни (за матеріалами центральних областей) // Сторінки воєнної історії України: 3б. наук. ст. 2008. Вип. 11. С. 148-165.

${ }^{10}$ Пастушенко Т.В. Будні нацистської окупації України у спогадах колишніх остарбайтерів // Сторінки воєнної історії України: зб. наук. ст. 2008. Вип. 11. С. 166-175.

${ }^{11}$ Яшан О. Повсякденне життя селян під час нацистської окупації 1941-1944 pp. (на матеріалах Центрального регіону України) // «Боротьба за Україну в 1943-1944 роках: Влада, Збройні сили, Суспільство». 3б. наук. праць / відп. ред. O.Є. Лисенко. Київ: Інститут історії України НАН України, меморіальний комплекс «Національний музей історії Великої Вітчизняної війни 1941-1945 років», Національний університет оборони України імені Івана Черняховського, 2014. С. 408-417.

${ }^{12}$ Дейнека Н. Румунський окупаційний режим та радянський рух Опору у південно-західному регіоні України і Молдавії (1941-1944 рр.). Одеса: Атлант, 2013. 221 с.

${ }^{13}$ Окупаційний режим в губернаторстві «Трансністрія» / Т. Вінцковський, Г. Кязимова, М. Михайлуца, В. Щетніков // Україна у Другій світовій війні: погляд з XXI ст. Історичні нариси. Київ: Наукова думка, 2010. T. 1. C. $413-446$.

${ }^{14}$ Михайлуца М.I. Православна церква на Півдні України в роки Другої світової війни (1939-1945). Одеса: Видво «ВМВ», 2008. 329 с.; Михайлуца М.I. Православне життя в Одесі: від револющії до сталінського одержавлення (1917-1945): монографія. Херсон: Олді-Плюс, 2019. 388 с., іл.

${ }^{15}$ Михайлуца M.I. Соціально-економічні аспекти буденного життя православного кліру в Трансністрії // Сторінки воєнної історії України. Київ, 2006. Вип. 10. Част. 1. С. 413-425.

${ }^{16}$ Щетніков В. До питання про втрати серед цивільного населення на півдні України під час німецькорумунської окупації 1941-1944 рр. (проблема джерел) // Сторінки воєнної історії України: Зб. наук. статей / НАН України. Ін-т історії України. Київ, 2005. Вип. 9. Част. 2. С. 351-358.

${ }^{17}$ Oстащук B.I. Розвиток медицини, медичної освіти та науки в Одесі в період румунської окупації (19411944 рр.) // Наукові праці: науково-методичний журнал. Т. 100. Вип. 87. Історичні науки. Миколаїв: Вид-во ЧДУ ім. Петра Могили, 2009. С. 78-82.

${ }^{18}$ Бабич А. Одесса 1941-1944 Пережить окупацію. Одеса: Черноморье, 2020. 592 с., 239 ил.
} 
усвідомлювало, що більшістю місцевого населення вони, перш за все, сприйматимуться як вороги. Враховуючи дану ситуацію, не дивно, що першими кроками, які дозволили окупаційному апарату тримати населення захоплених земель під контролем, стали впроваджені закони, які забезпечували безпеку румунських і німецьких військ від агресії та диверсій 3 боку сільського населення і водночас збереження колгоспного майна від знищення. Так, у наказі № 2451 від 3 жовтня 1941 р. було чітко зазначено, що у разі нападу та вбивства румунських солдат у будь-якому населеному пункті, адміністрацією будуть застосовані суворі покарання: за перший раз - буде розстріляно 10 людей із села, у випадку повторення факту нападу - розстріляють 50 осіб, у разі третього нападу - мірою покарання стане розстріл усіх мешканців населеного пункту, в якому відбувся акт злочину ${ }^{19}$.

Наказом № 17 очільник губернаторства Г. Алексяну попередив голів колгоспів і підлеглих бригадирів, що у разі виявлення саботажу та зриву роботи, або умисного знищення врожаю шляхом підпалу, - вищезазначені особи будуть розстріляні. Усі мешканці зобов'язувалися повідомляти органи окупаційної влади (примарів і жандармські пости) про людей, які незаконно перебували на території села, а також про шкідників, що своєю діяльністю протидіяли окупаційній владі. Населення, яке переховувало цих осіб, підлягало розстрілу ${ }^{20}$.

Про серйозність намірів румунського командування та цивільної адміністрації стало відразу зрозуміло після події, яка відбулася 23 жовтня 1941 р. Цього дня, радянські підпільники радіосигналом із Криму підірвали в Одесі будинок, в якому розташовувалася румунська комендатура, штаб 10-ї піхотної дивізії та німецькі зв'язківці. У відповідь на це окупанти винесли вирок: за кожного убитого румунського чи німецького офіцера або чиновника, розстріляти 200 комуністів, а за кожного рядового солдата - 100 комуністів. Водночас, залякуючи та попереджаючи місцеве населення про цей злочинний акт, румунське командування розмістило інформацію на шпальтах «Одеської газети» ${ }^{21}$.

Введення у дію низки законів і влаштування привселюдних страт за непокору, змушувало населення «Трансністрії», з одного боку, негативно сприймати окупантів, а 3 іншого - боятися радянських підпільників і диверсантів, за дії яких розплачувалися власним життям невинні люди.

Остерігаючись поширення на території губернаторства різноманітних чуток i дезінформації про перебіг військових дій на фронті й охороняючи окупаційний режим від можливих виступів місцевого населення, румунською адміністрацією було суворо заборонено проведення різного роду зібрань, процесій або утворення, без відповідного на те дозволу місцевої влади, політичних угрупувань. Мешканцям «Трансністрії» було заборонено поширювати та коментувати будь-яку інформацію про перебіг подій на фронті німецько-радянської війни, а також про місцезнаходження та розташування румунських і німецьких військ ${ }^{22}$.

Також румунська адміністрація запровадила на всій території цензуру та заборонило

\footnotetext{
${ }^{19}$ Державний архів Одеської області (ДАОО). Ф. Р-1932. Оп. 1. Спр. 661. Арк. 16.

${ }^{20}$ ДАОО. Ф. Р-1932. Оп. 1. Спр. 674. Арк. 144.

${ }^{21}$ Вінцковський Т., Кязимова Г., Михайлуца М. Окупаційний режим в губернаторстві «Трансністрія»... С. 438.

${ }^{22}$ Одесская область в Великой Отечественной войне 1941-1945 гг.: Док. и матер. / отв. ред. Н.И. Зотов и др. Одесса: Маяк, 1970. С. 166.
} 
таємне приватне листування. Для того, щоб цензори могли перевірити, чи немає там якоїнебудь таємної інформації, що могла б становити загрозу окупаційній владі, до поштових скриньок листи потрібно було вкидати не заклеєними. Листи зі змістом, які викликали підозру у нелояльності до окупаційної влади вилучалися i, звісно ж, до адресата не доходили.

Щоб протистояти впливовій ідеології попереднього режиму, румунська адміністрація запровадила заходи для знешкодження засобів радянської пропаганди, які діяли впродовж усього періоду окупації на теренах губернаторства. Румунами проводилась конфіскація всієї забороненої білышовицької літератури, друкарських пристроїв тощо ${ }^{23}$.

Місцевому населенню було заборонено зберігати будь-які грамплатівки, з яких «віяло» відкритою чи прихованою прокомуністичною пропагандою. Сільське населення, яке, у свою чергу, мало у власному користуванні заборонені носії агітації, зобов'язувалося здати їх упродовж 15-ти днів. За невиконання цього розпорядження, порушникам загрожувало ув'язнення терміном від 5 до 25 років. Від серпня 1943 р. усі мешканці губернаторства повинні були здати ще й наявні у них засоби радіозв'язку. За відмову виконувати даний наказ передбачалося покарання у вигляді позбавлення волі терміном від трьох до восьми років і штраф у розмірі від 100 до $500 \mathrm{RKKS}^{24}$.

Румунські чиновники здійснювали контроль за переміщенням місцевого населення у межах губернаторства. Наказом командувача військами у губернаторстві «Трансністрія» від 30 липня 1941 р. мешканцям заборонялося збиратись білыше ніж по 2 особи та під час комендантського часу пересуватися 38 години вечора до 5 години ранку ${ }^{25}$. Усі жителі були зобов'язані мати при собі документи, які б засвідчували особу, й у разі необхідності, надавати їх контролюючим органам. 31942 р. для того, щоб потрапити до сусіднього села, селянам потрібно було отримати дозвіл від представника сільської влади - примара. Для поїздки до населеного пункту, який знаходився у межах повіту, треба було при собі мати дозвіл претора та примарії, а для того, аби потрапити до іншого повіту - тільки дозвіл префекта, який видавався на підставі рішення примарії.

Однак, незважаючи на зазначені постанови та розпорядження, на практиці румунські зайди у глибинці «Трансністрії» все ж йшли на деякі поступки. Зокрема, мешканцям губернаторства нерідко дозволялося виїздити за межі губернаторства, але за умови наявності на те спеціального письмового дозволу. Тим жителям, які порушували встановлені правила, загрожувало покарання у вигляді позбавлення волі терміном від 1 до 2 років і грошовий штраф у межах від 200 до 300 марок $^{26}$.

Окупаційна влада 3 усього зазначеного унормування отримувала фінансовий зиск. Так, щоб отримати право на переміщення всередині того чи іншого повіту, сільському мешканцю потрібно було заплатити три марки. На дві марки більше становила плата за дозвіл на вільне пересування у межах губернаторства ${ }^{27}$.

\footnotetext{
${ }^{23}$ Одесская газета. 1942.19 апреля.

${ }^{24}$ Дейнека Н. Румунський окупаційний режим та радянський рух Опору у південно-західному регіоні України і Молдавії (1941-1944 рр.). Одеса: Атлант, 2013. С. 56.

${ }^{25}$ ДАОО. Ф. Р-2353. Оп. 1. Спр. 34. Арк. 3.

${ }^{26}$ Одесса. 1942. 25 июня.

${ }^{27}$ Левит И.Э. Участие фашистской Румынии в агрессии против СССР. Истоки, планы, реализация. Кишинев: Штиинца, 1981. С. 314.
} 
Ідея впровадження різноманітних грошових зборів для отримання населенням губернаторства, особливо мешканців сільських громад, різних довідок, стала одним із характерних ознак окупаційної політики румун на зазначених теренах. Для прикладу, згідно з постановою губернатора Г. Алексяну № 1882 від 4 вересня 1942 р. за отримання довідки про акт реєстрації народження або смерті мешканці «Трансністрії мали сплатити 50 пфенігів, за довідку про шлюб, за отримання підтвердження реєстрації у «Книзі про народження, смерть, шлюб» - одну марку ${ }^{28}$.

Румунське керівництво, окрім вище зазначеного, обмежувало й інші можливості населення. Так, з метою ефективнішого використання робочих рук у сільській місцевості 3 1942 р. під час весняно-польових робіт трудівникам, без відповідного на те дозволу претора та коменданта жандармерії, заборонялося влаштовувати різноманітні зібрання, гуляння, хрестини та весілля. У разі ж порушення цього рішення мешканці, які брали без відповідного на те дозволу участь у цих заходах, підлягали негайному арештові. Старости трудових громад, зі свого боку, були зобов'язані слідкувати за поширенням різноманітних чуток. У разі виявлення людей, які пліткували, потрібно було повідомити поліцію або жандармерію. Аналогічно сільські очільники мали вчиняти, якщо чужинці зупинилися у підконтрольному селі. Окрім цього, до обов'язків старост входили й інші дії: слідкувати за режимом пересування мешканців на території населеного пункту між восьмою годиною вечора та п'ятою годиною ранку; усіх виявлених порушників, відповідно, мали затримати та доправити до сільської управи, де на них накладалися грошові стягнення ${ }^{29}$.

Вочевидь, переслідуючи мету не допустити різноманітних зібрань серед селян, чиновники 3 настанням сутінок забороняли сільським мешканцям освітлювати свої будинки як із середини, так і ззовні. Старости ж сіл мали слідкувати за вчасним виконанням вимог цієї постанови ${ }^{30}$.

Нововведенням в окупованих землях стали спеціально розроблені румунськими чиновниками «Правила культури поведінки та спілкування» між старими та малими, підлеглим і керівником, між пересічним мешканцем і румунськими чиновниками, незалежно від займаної ним посади. Так, при зустрічі молодших зі старшими, перші повинні були зняти головний убір і схилити голову, якщо людина не мала головного убору, то вона повинна була вітатися підняттям правої руки долонею вперед на рівні голови (так званий румунський салют). Привітання мали звучати чітко та виразно. Перебуваючи в адміністративному приміщенні, усі присутні зобов'язувалися знімати головні убори та поклоном вітати старших. При вході до приміщення керівництва всі присутні мали піднятися 3 місць. Батьки та вчителі були зобов'язані з самого малечку привчати дітей до вихованості. Згідно 3 цими правилами усе населення «Трансністрії» 3 радістю на обличчі мало вітати вище керівництво, службовців претури, священиків, вчителів, агрономів, старост сільських управ, сільськогосподарських громад і бригадирів. Із представниками румунської влади населення зобов'язувалося вітатися винятково румунською мовою: «bună dimineața» (авт. «буне діміняца») - «доброго ранку»; «bună ziuа» (авт. «буне зіуа») - «доброго дня» та «bună seara» (авт. «буне сяра») - «доброго вечора». За виконанням розпорядження

\footnotetext{
${ }_{28}$ ДАОО. Ф. Р-2380. Оп. 1. Спр. 142. Арк. 24.

${ }^{29}$ ДАОО. Ф. Р-1932. Оп. 1. Спр. 441. Арк. 16.

30 Державний архів Миколаївської області (ДАМО). Ф. Р-1651. Оп. 1. Спр. 2. Арк. 55.
} 
слідкували місцеві чиновники. Ті ж мешканці, які відмовлялися вітатися румунською мовою, мали бути покарані ${ }^{31}$. Так, мешканець с. Балайчук Березівського повіту М. Швець був побитий місцевими жандармами тільки за те, що зустрівши на вулиці коменданта села, не зняв шапку та не вклонився останньому ${ }^{32}$.

Упроваджена румунською адміністрацією система покарань у вигляді грошових штрафів, позбавлення волі, фізичні тортури за невиконання наказів і розпоряджень, не залишала підокупаційному населенню краю іншого вибору, окрім упокоритися та працювати на загарбника.

За громадським порядком у сільській місцевості слідкували жандармські підрозділи і таємна політична поліція - сигуранца. Для проведення слідчих дій при повітах функціонували в'язниці, в яких утримувалися порушники закону, злочинці та ті, хто виявив будь-яким чином непокору румунській владі.

Слід відмітити, що слідчі дії проводилися цими ж каральними органами залежно від характеру та складу злочину або правопорушення. Методи досудового розслідування були вкрай примітивними та жорстокими: шляхом фізичного насилля та тортур, iз підозрюваного вибивали зізнання в інкримінованому йому злочині ${ }^{33}$.

Однак, незважаючи на низку наказів, постанов, все ж окупаційна влада масово фіксувала низку правопорушень з боку як міського, так і сільського населення, серед найпоширеніших виділяються: образи румунських чиновників, поширення усіляких чуток про румунське військо, становище на фронті, образи у бік румунської армії, зберігання вогнепальної зброї, підробка документів, переховування євреїв, знищення фуражу, отруєння води у криницях тощо. За такі дії звинувачених засуджували до різних термінів ув'язнення (від декількох тижнів до 10 років), смертної кари або каторжних робіт (терміном до 25 років). Часто окупанти застосовували штрафи (від 200 до 2000 лей), або арешт і штраф разом ${ }^{34}$.

Відмова виконувати роботи місцевим населенням тягла за собою цілу низку покарань і грошових штрафів. Наказом префекта Очаківського повіту, у випадках відмови мешканців вийти на прополювання бур'яну, загрожувало фізичне покарання у вигляді 10 ударів палищею та сплатою штрафу в розмірі п'яти марок. Якщо ж ті самі особи відмовлялися вдруге виконувати наказ - побиття зростало до 25 ударів, а штраф мали сплатити - 10 марок. За саботування цієї постанови втретє - людині загрожував військовий суд ${ }^{35}$.

Попри те, що румунська окупаційна адміністрація видала низку доволі жорстких законів і розпоряджень щодо запобігання крадіжок майна, що перебувало в окупаційній власності, підпорядковане місцевим адміністративним органам. Однак скрутне соціальноекономічне становище населення змушувало декого вибудовувати свої власні стратегії виживання на кримінальному підгрунті. Свій вибір зробили у такий спосіб селяни трудової

\footnotetext{
${ }^{31}$ ДАМО. Ф. Р-2512. Оп. 1. Спр. 1. Арк. 36-37.

${ }^{32}$ Одесса в Великой Отечественной войне Советского Союза: Сб. док. и матер. в 3-хт. / отв. ред. И.В. Бортников. Т. 2: 17.10 .1941 - 9.4.1944. Одесса: Одесское областное издательство, 1949. С. 177.

${ }^{33}$ Никульча И.Я. Компоненты и характеристика судебно-репрессивной системы в Транснистрии (19411944 гг.) // Південь України: етноісторичний, мовний, культурний та релігійний виміри: зб. наук. праць V Міжнар. наук. конф., 24-25 квіт. 2015 р., Одеса / відп. ред. М.І. Михайлуца. Одеса: ОНМУ, 2015. С. 212.

${ }^{34}$ Вінцковський Т., Кязимова Г., Михайлуца М. Окупаційний режим в губернаторстві «Трансністрія»... С. 439.

${ }^{35}$ ДАМО. Ф. Р-1651. Оп. 1. Спр. 2. Арк. 60.
} 
громади № 3 с. Синюхин Брід Голтянського р-ну - I. Половий і В. Цабленко. За поцуплені 800 кг кукурудзи, вони отримали по 25 ударів гумовою палицею, сплатили штраф у розмірі 200 крб. кожен та по три доби відбули арешту на жандармському посту. На додаток Івана Полового відразу після зізнання у крадіжці було звільнено із займаної ним посади бригадира ${ }^{36}$.

Незважаючи на те, що керівництвом губернаторства було монополізоване виготовлення різноманітних горілчаних напоїв, сільське населення у кустарних умовах активно виготовляло контрафактний продукт (самогон), як для власних потреб, так і 3 метою особистої вигоди. Так, у селах Врадіївського району поширення самогоноваріння стало стихійним явищем, що змусило керівництво місцевої адміністрації перейти до рішучої боротьби з даною проблемою. Для цього влада району впровадила наказ № 8 від 8 листопада 1941 р., в якому зазначалося наступне: у зв'язку із систематичними п'янками серед місцевого населення, які призвели до постійних бійок, збільшенню різноманітних хуліганських вчинків, зростанню числа крадіжок і розпусних дій, що поставило під загрозу успішне завершення осінніх сільськогосподарських робіт зі збору врожаю, керівництво Врадіївської поліції та старости сільських управ були зобов'язані вжити рішучих заходів для ефективного вирішення цієї проблеми. Мешканці, які були причетні до самогоноваріння, мали сплатити 250 крб. (так у документі) штрафу, або відбути 10-ти денне ув'язнення у районній в'язниці. Знайдена апаратура 3 виготовлення самогону підлягала негайному знищенню, а вилучена продукція йшла на потреби районної лікарні й амбулаторії ${ }^{37}$.

Обов'язки слідкувати за дотриманням правопорядку в селах, а також, як сільське населення дотримується впроваджених цивільною адміністрацією наказів і постанов, були покладені на плечі румунських жандармів та вояків. Саме у руках цих представників румунської влади знаходилось право вирішувати долі, як окремо взятої людини, так і цілої сільської громади.

Постійно зростаючі економічні потреби, особливо у сільськогосподарській продукції, керівництво губернаторства «Трансністрія» вирішувало винятково за рахунок сільського населення губернаторства, переважно членів трудових громад. Під контролем румунів перебували норми споживання жителями пшениці та виготовлених 3 неї різноманітних круп, борошна та хліба. Так, спеціальним розпорядженням губернаторства «Трансністрія» за № 3993 та розпорядженнями префектур повітів (наприклад Ананьївського повіту за №972) населенню було заборонено перемелювати зерно пшениці на крупу без спеціального на те дозволу чиновників префектури. Визначалися норми споживання пшеничної крупи. На місяць родині з трьох осіб дозволялося перемелювати на власні потреби лише 20 кг пшениці. Якщо ж в сім’ї було більше трьох людей, то на кожного наступного члена родини дозволялось перемелювати додатково 5 кг зерна. Старости сільських управ були зобов'язані видавати відповідні дозволи та вести їх облік. У випадку виявлення порушень, на кшталт видачі в одні руки двох, а то й більше дозволів на перемелювання пшениці, староста ніс усю матеріальну відповідальність ${ }^{38}$.

Окупаційною владою губернаторства також була встановлена денна норма

\footnotetext{
${ }^{36}$ ДАМО. Ф. Р-2540. Оп. 1. Спр. 514. Арк. 1.

${ }^{37}$ ДАМО. Ф. Р-2512. Оп. 1. Спр. 285. Арк. 3.

${ }^{38}$ ДАОО. Ф. Р-1932. Оп. 1. Спр. 15. Арк. 5.
} 
споживання хліба. Згідно з наказом №3998 від 26 листопада 1941 р. денна норма споживання хліба становила 500 г на людину, яка досягла п'ятирічного віку. Щомісяця на одну родину для харчових потреб виділялося додаткових 20 кг борошна другого сорту. Міська управа Очакова ввела карткову систему на хліб. Весь хліб мав випікатися винятково 3 муки другого сорту як для армії, так і населення. Усі сільські млини Очаківського повіту отримали право перемелювати пшеницю в борошно тільки другого сорту. Деякі пом'якшення для населення окупаційна влада робила під час християнських свят: Різдва та Великодня. На ці свята дозволялося молоти біле борошно, але не більше 5 кг на одну родину. Щоб перемолоти пшеницю на борошно, усі бажаючі повинні були спочатку отримати відповідний дозвіл у сільського примаря. За надані послуги мірошник вираховував $12 \%$ уже готової продукції.

у випадку невиконання зазначеного наказу перед судом за звинуваченнями в економічному саботажі несли відповідальність старости села, млинарі та всі мешканці населеного пункту, в якому були виявлені махінації ${ }^{39}$. Проте, вже у вересні 1942 р. постановою за № 1881 губернатора Г. Алексяну населенню заборонялося на власні потреби перемелювати пшеницю та жито. Щомісяця на одну людину було дозволено молоти лише 13,5 кг ячменю та 3 кг кукурудзи, з яких 10\% перемеленого зерна за надані послуги забирав мельник. Якщо ж мешканці відмовлялися молотити ячмінь - їм дозволялося молоти 15 кг кукурудзи ${ }^{40}$.

Цією ж постановою визначався склад хліба. Населення мало право споживати хліб, випечений 3 наступних інгредієнтів: 65\% ячмінної муки, 20\% кукурудзяної муки та 15\% домішувалася картопля ${ }^{41}$.

Слід зазначити, що згадане вище губернаторське розпорядження передруковували на місцях, представляючи його уже як розпорядження місцевої адміністрації, за невиконання якого жорстко карали. За порушення розпорядження префектури Очаківського повіту за № 19 від 24 жовтня 1942 р. шістьох мешканців села Анчекрак і п'ятьох жителів села Володимирівка було відправлено до суду військового претората за спробу перемолоти пшеницю на Александрофельскій млинарні. Ті ж господарі, у розпорядженні яких ще залишалася пшениця, були зобов'язані до 20 листопада 1942 p. здати наявні запаси до району й отримати, натомість, ячмінне зерно ${ }^{42}$.

Однією зі складових повсякденного життя та побуту населення є перебіг тих чи інших захворювань і відповідна організація медичного забезпечення мешканців окупованих земель. В умовах воєнного протиборства й окупаційного повсякдення населення «Трансністрії» значною мірою відчуло на собі проблеми та наслідки санітарноепідеміологічного характеру, які особливо гостро проявлялися у сільській місцевості. На цих теренах особливо поширювалися такі інфекційні та небезпечні захворювання для населення - холера, чума, висипний тиф, педикульоз. Вельми поширеними були дерматологічні та венерологічні захворювання, які ширилися внаслідок нехтування особистими санітарно-гігієнічними нормами та неконтрольованими статевими

\footnotetext{
${ }^{39}$ ДАМО. Ф. Р-1721. Оп. 1. Спр. 65. Арк. 2.

40 ДАМО. Ф. Р-1718. Оп. 1. Спр. 351. Арк. 80.

${ }^{41}$ Ibid. Арк. 803в.

${ }^{42}$ Николаевщина в годы Великой Отечественной войны 1941-1944 гг.... С. 89.
} 
відносинами. Перебіг цих хвороб становив значну загрозу для здоров'я та життя як адміністративного, так і військового апарату окупантів, а також цивільного населення губернаторства.

Оскільки радянська медична система була зламана, у перші місяці окупації румунською адміністрацією було створено Дирекцію охорони здоров'я. На нашу думку йти на такі кроки окупаційну владу примушувала радше турбота не стільки про місцеве населення, скільки про особистий стан здоров'я окупаційного апарату та війська.

Зіткнувшись із низкою небезпечних захворювань, серед яких основне місце займав висипний тиф - гостре інфекційне захворювання, що передавалося вошами, симптоми якого проявлялись лихоманкою, своєрідним висипом на шкірі, а також ураженням нервової та серцево-судинної систем, і яке набуло широкого поширення та викликало серйозне занепокоєння, що примусило окупаційну владу утворити Надзвичайну комісію для подолання цієї хвороби та запобігти іï розповсюдженню. Комісією було розроблено та впроваджено у дію низку постанов, спрямованих на покращення санітарно-гігієнічних умов життя мешканців «Трансністрії». Заходи для боротьби 3 інфекційними захворюваннями зводилися до примусового підтримання людьми їx елементарної суспільної й особистої гігієни та місць їх постійного проживання.

Боролися з інфекцією шляхом випрасовування та вижарювання особистих речей у гарячих пічках, а також приведенням будинків і подвір'їв у належний вигляд. Значної уваги місцеві органи окупаційної влади приділяли відновленню та налагодженню діяльності сільських лазень. У двотижневий термін було відновлено роботу лазень у селах Стрюкове, Ісаєве, Ново-Андріївка та у Черновому. У селах, де були відсутні лазні, їх будували при лікарнях. Враховуючи те, що серед дітей було багато носіїв різноманітних хвороб, влада приділяла значну увагу санітарно-епідеміологічним заходам серед шкільних і дитячих закладів. Зазначена вище комісія зобов'язала місцеві органи влади провести роботу та повністю ліквідувати завошивленість серед учнів шкіл шляхом щотижневого купання вдома та прання білизни. Вчителі щоранку були зобов'язані опитувати дітей, чи немає хворих серед рідні; у разі виявлення таких - зобов'язувалися повідомляти про це у відповідні установи ${ }^{43}$.

Оскільки централізованого водопостачання в сільських громадах не існувало, влада вирішила усі криниці як громадські, так і приватні, відремонтувати, якщо була така потреба, забезпечували їх кришками та відрами. Обов'язковому щомісячному огляду підлягали усі особи, які працювали у сфері харчової торгівлі. На боротьбу з інфекційними захворюваннями було мобілізовано у межах району увесь медичний персонал. Учителі проводили роз'яснювальну роботу «про необхідність санітарної чистоти в будинках, ролі вошей та бруду в розповсюдженні різноманітних хвороб» ${ }^{44}$.

Однією 3 перешкод, яка стояла на заваді населенню губернаторства звертатися до кваліфікованих спеціалістів, стало впровадження румунською владою оплати за медичне обслуговування. Так, консультація лікаря коштувала - 12 марок, операція - 20, рентген 20 , а за харчування в лікарні щоденно сплачувалося 2 марки. Така політика фактично унеможливила доступ для отримання медичних послуг як міського, так і сільського

\footnotetext{
${ }^{43}$ Ibid. Арк. 54.

${ }^{44}$ Ibid. Арк. 75.
} 
населення губернаторства ${ }^{45}$.

Отже, на окупованих землях межиріччя Дністра та Південного Бугу румунська адміністрація задля ефективного керівництва й упокорення місцевого населення впровадила низку законів, які, у першу чергу, були направлені на убезпечення окупаційних військ і чиновницького апарату від провокацій і збройних виступів з боку місцевого населення. Також низка наказів і постанов регламентували життя, поведінку та норми споживання населенням хліба та круп, що стало однією з форм експлуатації румунською адміністрацією сільського населення на досліджуваній нами території. Проте, незважаючи на низку прописаних покарань, за недотримання наказів та постанов, все ж місцеве населення щораз іх саботувало. Що стосується налагодження медичного забезпечення населення, то румунська влада, незважаючи на певні зусилля, так і не спромоглася налагодити її ефективну діяльність.

На нашу думку, діяльність румунської адміністрації, у першу чергу, була направлена на економічну експлуатацію сільськогосподарського потенціалу захоплених ними земель, де сільським жителям відводилось роль мовчазних виконавців ворожих наказів і планів, ускладнюючи і до того важке життя підокупаційного населення.

\section{Oleksandr Osypenko}

\section{Regulation of the Daily Life of the Rural Population of «Transnistria» 1941-1944}

Abstract: The article analyzes the laws and the orders of the Romanian occupation administration, which were aimed at regulation of the daily life of the rural population of interfluve of the Dniester and the Southern Bug in 1941-1944. It was established that the vast majority of orders were aimed at ensuring the safety of the occupying forces and the administration. Also, in the article was indicated, that a number of punishments were introduced in the form of fines and imprisonment for hiding underground workers, destruction of agricultural equipment or refusal to carry out occupation orders.

The system of punishments in the form of fines, imprisonment, physical torture for non-compliance with orders and directives, that were introduced by the Romanian administration, didn't left the occupied population of the land with no choice, expect to submit and work for the invader.

Arrangement of public executions for disobedience forced the population of «Transnistria» to perceive the occupiers negatively, but on the other - to fear Soviet underground workers and saboteurs, for whose actions innocent people paid with their own lives.

In the article were analyzed the laws and regulations of the governing bodies of the authorities of governorship, which set the amount of grinding wheat into groats and determined the daily norm of bread consumption by one person. Everybody who want to grind grain firstly should obtain permission from the local administration. Subsequently the rural

${ }^{45}$ Лебедев Н.И. Крах фашизма в Румынии... С. 319. 
population was allowed to grind barley and corn in clearly defined proportions instead of wheat. Peasants who violated the relevant orders were threatened with imprisonment and fines.

Also, in the article is also covered the medical support of rural population. It has been established that the Romanian civil administration has pursued a policy aimed at improving the sanitary and epidemiological situation. This policy was limited to maintaining the cleanliness of the permanent residence of the peasant and his family, compliance with the rules of personal hygiene, as well as constant checking and questioning of children about the health of their loved ones by teachers at schools. However, the introduction of payment for medical services effectively prevented access to medical services for both urban and rural populations in the governorship.

Keywords: occupation, «Transnistria», rural population, laws, nourishment, diseases 